WIELKIE TEMATY KULTURY W LITERATURACH SŁOWIAŃSKICH

Slavica Wratislaviensia CLXVIII • Wrocław 2019•AUWr No 3875

DOI: 10.19195/0137-1150.168.24

Data przesłania artykułu: 15.05 .2017

Data akceptacji artykułu: 8.01.2018

\title{
LIBOR MARTINEK
}

Uniwersytet Wrocławski, Polska

Slezská univerzita v Opavě, Republika Czeska

\section{Poetika smrti v raném díle Bohuslava Reynka}

Básník, překladatel, grafik Bohuslav Reynek se narodil 31 května 1892 v Petrkově u Havlíčkova Brodu na Českomoravské Vysočině v rodině statkáře Bedřicha Reynka ${ }^{1}$.

V roce 1902 otec statek v Petrkově pronajal a celá rodina se odstěhovala do Jihlavy, tehdy vesměs německého města (s početnou židovskou menšinou ${ }^{2}$ ), kde Reynek studoval reálné gymnázium. Získal zde dobrou jazykovou průpravu, která mu později umožnila překládat $\mathrm{z}$ francouzštiny a němčiny, pasivně uměl anglicky. Na této škole měl na něho značný vliv učitel Max Eisler (1881-1937), pozdější docent dějin umění na vídeňské univerzitě, který v něm probudil zájem o malîrství a poezii. Z té doby (kolem roku 1909) pocházejí první Reynkovy dochované kresby a olejomalby z okolí Jihlavy. Po maturitě v záŕí 1912 absolvuje léčebný pobyt v Dalmácii na ostrově Rab, odkud přiváží jedny z prvních zachovalých kreseb. $\mathrm{V}$ tomto roce se také pokouší o básnickou tvorbu, kterou shrnul později do sbírky juvenilií Žízně 1912-1916. Sbírka vyšla v roce 1921, ale už předtím byly jednotlivé básně publikovány samostatně. Po maturitě v roce 1912 odešel Reynek na otcovo přání do Prahy, kde v říjnu začal studovat zemědělský obor na c. k. Vysoké škole technické. Studium pro absolutní nezájem opustil již v listopadu a vrátil se do Petrkova, kde pracoval jako zemědělský adjunkt na otcově statku. V roce 1912 uskutečnil svou první cestu do Francie (přes Paříž se

${ }^{1}$ Kořeny Reynků je podle rodinné tradice zapotřebí hledat v románských zemích. Nejstarší známý Reynek tohoto rodu — Jakub je uveden v matrice jako Reňk a v háčku nad „n“ se spatřuje stopa španělského znaménka tilde. Jméno samo pak odvozují od adjektiva renco — kulhavý. Rodinný předek z Iberského poloostrova se do lesnaté krajiny u Světlé nad Sázavou snad dostal v pobělohorské době, kdy do Čech přišlo mnoho španělských vojáků, kteří se později zcela počeštili.

${ }^{2}$ Kontakt se židovskými spolužáky mohl ovlivnit i Reynkův zájem o Starý zákon a o Knihy proroki. 
vypravil do Bretaně) a v této době také začal psát poezii a malovat, záhy se pustil i do překladů z cizích jazyků3 .

Reynkovu osobnost a utváření jeho uměleckého profilu musíme proto vnímat v trojjediném talentu literárním, výtvarném i překladatelském, nebot' tyto činnosti, ve kterých — jak ukážeme v našem př́spěvku — se stal mistrem, navzájem na sebe plodně působily.

Reynek od roku 1914 velmi úzce a dlouhodobě spolupracoval se staroříšským vydavatelem Josefem Florianem (1873-1941); jeho překlady, ale i původní práce a grafiky spoluvytvářely charakter nejrůznějších edic Dobrého díla. K výtvarné spolupráci s Dobrým dílem, ale i se Sešity poezie — vlastní bibliofilskou edicí, v níž vyšly jak některé Reynkovy práce, tak překlady z německé a francouzské poezie (1921-1927, celkem 7 svazků) — přizval rovněž Josefa Čapka (1887-1945), se kterým se seznámil v roce 1917. Reynek spolupracoval také s brněnským vydavatelem Janem V. Pojerem (1900-1984), přičemž svými edičními náměty i překlady spoluvytvořil charakter jeho bibliofilské edice Atlantis, a s Vlastimilem Vokolkem (1903-1985) v Pardubicích.

Pro Reynka, jenž byl hluboce věřící katolík, měl Florian zásadní význam z hlediska značně výlučného, ultramontánního a apokalyptického katolicismu, který staroříšský vydavatel hlásal zejména pod vlivem četby francouzského náboženského myslitele a spisovatele Léona Bloy (1846-1917) a jehož dílo téměř celé přeložil. Druhým impulzem, který Reynka nakrátko vychýlil z jeho petrkovského stabilitas loci, bylo město Grenoble ve francouzských Alpách i blízká La Saletta, místo zjevení Panny Marie 19.9.1846, jejíž poselství ovlivnilo Floriana, Reynka nebo Jana Zahradníčka (1905-1960), jehož toto mariánské zjevení inspirovalo ke stejnojmenné sbírce z roku 1947. Každoroční cesty do Francie Reynek podnikal od roku 1923. V Grenoblu se prostřednictvím překladu sbírky Ta vie est là (1923), jejíž titul bychom mohli přeložit jako Váš život je tady, seznámil s její autorkou, francouzskou básnírkou Suzanne Renaud (1889-1964), která se za něj v roce 1926 provdala. Od sňatku manželé žili pravidelně půl roku ve Francii ${ }^{4}$, kde se narodili i oba jeho synové Daniel ${ }^{5}$ a Jiř́i ${ }^{6}$, a půl roku v Petrkově. Od roku 1936 Reynek zůstal trvale v Petrkově, kde se po otcově smrti ujal řízení statku. Za okupace v roce 1943 byl Reynek přinucen pronajmout statek Němcům a v únoru 1944 musel Petrkov zcela opustit; přestěhoval se s rodinou do Staré Říše k dětem

${ }^{3}$ V úvodním vykreslení Reynkova života a tvorby jsme vycházeli z údajů obsažených v hesle B. Reynek, které sestavil Jaroslav Med v rámci Lexikonu české literatury 3/II, $P-\check{R}$, Praha 2000, s. $1242-1245$.

${ }^{4}$ Ve Francii se Reynek spř́telil zejména s Jeanem Gionem (1895-1970), Maxem Jacobem (1876-1944) a Georgesem Bernanosem (1888-1948).

${ }^{5}$ Daniel Václav Reynek (9.6.1928 La Tronche u Grenoblu-23.9.2014 Petrkov), za totality řidič náklad'áku, věnoval se fotografování a tiskařství. Fotografickou tvorbu začal vystavovat až po roce 1990, publikoval ji i knižně a formou kalendářù.

${ }^{6}$ Jiř́i Michael Reynek (5.7.1929 Paříž-15.10.2014 Petrkov), za totality krmič prasat, poté byl kostelníkem ve Svatém Kříži. Umělecky se realizoval především jako grafik, prozaik a překladatel (mimo jiné díla Jeana Giona, Francisa Jammese, Marie Noël, Roberta Pingeta, Henri Pourrata). 
J. Floriana. V roce 1945 se vrátil a hospodařil na statku, který byl v roce 1949 zestátněn. Reynek zde pracoval jako zemědělský dělník až do roku 1957. Ve svém domě v Petrkově básník zemřel 28.9.1971.

Do literatury Reynek vstoupil po první světové válce. V jeho tehdejších sbírkách je velmi silná frekvence motivů smutku, rozpadu a tlení, jež souzní, zejména svou barevností, s poetikou expresionismu. Od německého expresionismu (v této době překládal díla autorů tohoto směru) se hluboce věřící křestan Reynek odlišuje tím, že smutek je pro něj především konstruktivní silou, důsledkem porušenosti lidského bytí dědičným hříchem. Reynkovu básnickou tvorbu 20. let, sbírky Rybí šupiny (1922), Had na sněhu (1924), Rty a zuby (1925), tak určuje silná expresivita výrazu, arytmický verš a tíhnutí k až barokní antitetičnosti. Básníkova spiritualita, hledající často zobecnění v biblických, zejména starozákonních motivech a v liturgii, chce objektivizovat utrpení a smrt jako jedinou cestu $\mathrm{k}$ radosti a $\mathrm{k}$ Bohu.

Po více než desetiletém odmlčení, kdy se věnoval především výtvarné tvorbě, expresivita z Reynkovy poezie mizí a vše se podřizuje prostotě slova i obrazu; ze smrti-rozpadu se stává smrt-vykupitelka, sbírky Setba samot (1936), Pietà (1940). Básník se soustřed'uje na hledání pokorné lásky ke všemu, co žije a trpí, na objevování krásy v nejprostších věcech svého venkovského okolí a v proměnlivé stálosti př́rody. Neodmyslitelnou součást jeho poezie představuje prŕŕroda rodné Vysočiny, nikoli jako zdroj impresí, ale jako součást křest’anského podobenství o pádu a vykoupení. Reynkova spiritualita se oproštuje od vnějškově liturgických projevů, včetně biblických motivů, a toto vnitřní oproštění se projevuje i ve struktuře jeho veršů, kdy se verš stává až gnómicky strohý, zvyšuje se veršová rytmičnost a zcela se vytrácí dřive často zastoupený žánr básně v próze sbírky Podzimni motýli (1946), Sníh na zápraži (1969), Mráz v okně (1969).

Reynkova překladatelská činnost je významná především svou objevitelskou iniciativou, s níž vnášel nová významná literární jména do českého kulturního kontextu. Jeho překlady poezie jsou vesměs osobitými uměleckými díly, která citlivě tlumočí básnické kvality překládaného autora. Reynek se pod Florianovým vlivem a častými pobyty ve Francii stal zasvěceným znalcem francouzské literatury, z níž do české literatury často jako první uvedl a přetlumočil řadu významných autorů, zejména, ale nikoli výlučně, básníků katolické provenien$\mathrm{ce}^{7}$. V oblasti německé literatury byl Reynek de facto prvním českým překladatelem expresionistických básníků. V takzvaném expresionistickém desetiletí (1910-1920) se nevyhnul téměř žádnému z typických představitelů tohoto hnutíi ${ }^{8}$. Nejzávažnějším překladatelským činem bylo jeho přetlumočení veršů Georga

${ }^{7}$ Georges Bernanos, Léon Bloy, Paul Claudel, Tristan Corbière, Jean Giono, Max Jacob, Francis Jammes, Jean de Lafontaine, Charles Péguy, Jehan Rictus, Paul Valéry, Paul Verlaine a jiní; zaujal jej také francouzsky píšící Litevec žijící ve Francii Oscar Vladislav de Lubicz-Milosz (1877-1939), jehož drama Mefiboseth (1914) přeložil v roce 1919 do češtiny.

8 Theodor Däubler, Kasimir Edschmid, Albert Ehrenstein, Richard P. Ernst, Georg Heym, Else Lasker-Schülerová, René Schickele a jiní. 
Trakla (1887-1914) — Básně, Šebestián ve snu —, jež výrazně ovlivnily soudobou českou poezii (Františka Halase, Viléma Závadu, Jana Zahradníčka).

Již jsme uvedli, že se Reynek během studia na jihlavské reálce začal věnovat kresbě a malbě. Zpočátku Reynek navázal kontakty se členy skupiny Osma a Skupiny výtvarných umělců, později i se skupinou Tvrdošíjní. Ve 20. letech vytvořil v souvislosti se spoluprací s Florianovým nakladatelstvím ve Staré Říši expresionistické linoryty. Stejně jako básnická, tak i Reynkova grafická tvorba se dočkala plného oficiálního uznání až po pádu komunistického režimu v 90. letech, byt' se o jeho výtvarné práci vědělo i mezi mladší generací výtvarných umělců i teoretiků 60 . let ${ }^{10}$.

Dílo Bohuslava Reynka bylo analyzováno zejména po roce 1989 z několika úhlů pohledu, které vzájemně nasvěcují jeho osobnost a dílo. Jsou to studie z oblasti literární vědy ${ }^{11}$, přičemž kritické ohlasy na výtvarné dílo nejsou (až na výjimky, které umožňují pochopit prolínání básnických a výtvarných motivůำ) předmětem našeho výzkumu, proto odkazujeme na př́slušnou literaturu předmě$\mathrm{tu}^{13}$. Dodejme in margine těchto zkoumání, že autor tohoto př́spěvku se zabýval nikoli zanedbatelným fenoménem značného množství zhudebnění Reynkových básnických textů v české populární i vážné hudbě ${ }^{14}$ zejména po roce 1989 a současnou recepcí Reynkova díla v Polsku ${ }^{15}$, kde se zásluhou několika příznivců básnického a výtvarného díla tohoto petrkovského solitéra těší určitému, sice pozdnímu, ale zaslouženému zájmu.

${ }^{9}$ Reynek překládal i křest’ansky orientované německé idyliky Adalberta Stiftera (18051868) a Richarda Billingera (1890-1965).

10 Kunsthistorička Věra Jirousová (1944-2011) se Reynkem zabývala ve své disertační práci Grafické a básnické dílo Bohuslava Reynka, obhájené na FF UK v roce 1969. Pracovala také na obsáhlé monografii o B. Reynkovi, kterou již nedokončila.

${ }^{11}$ Kritické ohlasy na Reynkovo dílo obsahuje např́klad Výběr z literatury o básnickém díle Bohuslava Reynka, který sestavil Mojmír. Trávníček a jenž byl otištěn v Básnických spisech B. Reynka z roku 1995 a nejnověji v autorově hesle v internetovém Slovniku českých spisovateli po roce 1945; k dispozici je také Bibliografická databáze ÚČL AV ČR, která heslo vhodně doplňuje o novější články a studie o autorovi od roku 1961; do doby před rokem 1961 sahá bibliografie Reynkovy básnické a překladatelské tvorby, kterou sestavil Josef Glivický a Vladimír Vokolek v souboru dopisů Josefa Čapka B. Reynkovi Nepřicházeji vhod — vydáno v roce 1970, s úvodem Ludvíka Kundery.

12 Paralelami mezi Reynkovou básnickou a grafickou tvorbou se zabývala Dagmar Halasová v monografii Bohuslav Reynek, Brno 1992.

13 Např́klad Bohuslav Reynek 1, 2. Katalog výstavy k 100. výroči narození, Brno 1992, 1993; zde studie Jiř́iho Šerýcha, Renaty Bernardi, Věry Jirousové, Jaroslava Meda, Karela Srpa, Jana Šulce a podrobná chronologie Reynkova života i tvorby; 2. svazek obsahuje soupis výtvarného díla Bohuslava Reynka.

${ }^{14}$ L. Martinek, Kopce jsou lysé, sníh hoři. Zhudebněná poezie Bohuslava Reynka, ,Religious and Sacred Poetry. An International Quaterly of Religion, Culture and Education“ 2014, č. 4 (8), s. $93-112$.

${ }^{15}$ L. Martinek, Bohuslav Reynek - Samotář z Petrkova, „Slavica Wratislaviensia“ 160, 2015, s. 85-93. 
Chceme-li přispět kamínkem do mozaiky literární interpretace Reynkova díla, musíme se zaměřit na zkoumání aspektů a součástí jeho tvaru, jenž se vyvíjel v čase, aby dosáhl kanonizované podoby finálních sbírek. Martin C. Putna vyslovil domněnku, že po prvopočátcích básnické tvorby ovlivněné různými čtenářskými i výtvarnými zálibami, „zralý, kanonický Reynek se vynořuje až po celém desetiletí sbírkou Setba samot (1936)“16. Chtěli bychom se proto soustředit na rané období Reynkovy tvorby, kdy se jeho poetika teprve vytváŕí a kde se dá vysledovat několik etap jejího vývoje ${ }^{17}$. Konkrétně se zaměříme na motivy smrti v Reynkových prvních básnických sbírkách a na jejich zařazení do př́íslušného kontextu v rámci jeho díla (autorské poetiky), na autorův náhled na svět (reálný i metafyzický) i dobový literárněhistorický kontext. V každém př́ípadě topos smrti nabýval na významu v české literatuře konce 19. století v různých souvislostech (otázka sebevraždy, role ženy ve vztahu ke společenskému náhledu na smrt a umírání, existenciální úzkost ve spirituální tvorbě křest’ansky zaměřených autorů apodobně). Od toho se odvíjí způsob traktování motivu smrti v dílech katolicky orientované meziválečné poezie a prózy i problematika artikulace religiozity v dílech Jana Čepa, Jakuba Demla, Jaroslava Durycha, Reynka či Zahradníčka, abychom jmenovali ty nejvýznamnější osobnosti z hlediska vytčeného tématu našeho příspěvku. Jde vesměs o autory,

v jejichž básnické tvorbě či v některém jejím období tato tematika netvoří fragmentární část, nýbrž je přesvědčivým dokladem autorovy reflexe fenoménu smrti i uměleckým zprostředkováním jeho emocionálních i etických postojů, a stává se tak úhrnným vyjádřením jeho životní zkušenosti či přesvědčení ${ }^{18}$.

Reynek vstupuje do literatury jako básník i jako překladatel poezie ještě na stránkách symbolistně-dekadentní „Moderní revue“ vedené Arnoštem Procházkou. Čtvrté, sedmé a desáté číslo revue 28. svazku 20. ročníku přineslo v průběhu roku 1914 první Reynkova díla — básně ve verších i v próze. Reynkovy prvotiny se tak octly vedle básní Jiř́ho Karáska ze Lvovic, Růženy Jesenské, Rudolfa Medka nebo Josefa Hory. Ve stejném ročníku a svazku byly rovněž zveřejněny první básníkovy překlady z díla Francise Jammesa, André Suarèse a Novalise, které vhodně doplnily ukázky z tvorby Rémyho de Gourmonta, Paula Verlaina a dalších autorů v překladu jiných přispěvatelů. Reynkovy počiny pak brzo zamíŕily jinam, prostor vlastní působnosti našel $\mathrm{v}$ edičních řadách, které vydával Florian ve Staré Říši na Moravě. Pro Florianovy edice Dobré dílo, Nova et Vetera, Archy a Kursy překládal od roku 1914 téměř pětatřicet let a podílel se na

${ }^{16}$ M. C. Putna, Proměny neměnného, [in:] Bohuslav Reynek: Pieta v lod'ce. Grafické a básnické dílo, ed. V. Jirousová, Praha 2002, s. 67.

${ }^{17}$ Nynější příspěvek se proto zásadně liší od našeho, výše již citovaného a komplexněji zaměřeného článku (život a dílo v jeho úvodu) Bohuslav Reynek - Samotář z Petrkova, nebot' ten byl orientován kromě na recepci básníkova díla v Polsku a ke konci také na zhudebnění jeho poezie českými hudebními skupinami a interprety.

${ }^{18}$ M. Záborcová, Fenomén smrti v české literatuře 20. století, disertační práce, Praha 2007, s. 12. 
vydavatelském úsilí Staré Říše nejen za Florianova života, ale i po jeho smrti až do nuceného uzavření staroříšské činnosti po roce 1948. Setkání Reynka, jinak hluboce zakořeněného $\mathrm{v}$ tradičním katolicismu, $\mathrm{s}$ Florianem nese rysy nábožensko-psychologického procesu, který M. C. Putna označuje za „vnitřní konverzi“. V básních z let 1912-1914 ještě promlouvá Reynek před setkáním s Florianem, kdy je inspirován literaturou kolem „Moderní revue“ a jeho vzorem je z českých autorů Karel Hlaváček (1874-1898). Pod jeho vlivem tyto první Reynkovy verše usilují slít a stavit jinošskou dychtivost s melancholickou umdleností, vyhledávají výrazy starosvětsky vznešené a hrdě nednešní19.

Básně, které byly publikovány v „Moderní revue“ a jež pak zahajují sbírku Žizně 1912-1916, se vyznačují dožívajícími postupy symbolistně dekadentního lartpourlatismu, vycítíme blízkost secese, což jistý artismus a secesní barevnost této rané Reynkovy poezie také podporuje. Nicméně již v novalisovsky ${ }^{20}$ laděné básni Písen̆ raněného ptáka, otevírající sbírku, se čte hned prvním verši toto vyznání: „Loučím se s vámi před sladkou smrti““21. Symbol poraněného ptáka, jenž nepřijímá smrt pasivně, ale v odevzdání, v němž je přítomen celý dosavadní život, který končí na nejvyšší ze skal, na niž dokáže dolétnout, předznamenává skutečnost, že v Reynkově poezii nebude smrti odepřeno místo. V citovaném textu nacházíme i onu secesní barevnost a ornamentálnost (opojné dálky, modravý obzor, černé krůpěje, zelené kry). Přítomnost smrti je patrná i v oblacích, z nichž „tiše kyne bílé dlaně krása, / jež hlavy modřínů před smrtí učesala“22 (Podzim). Ještě explicitněji se dotýkáme smrti v básni Panychida ${ }^{23}$, kterou Reynek věnoval svému předčasně zesnulému spolužákovi a nejbližšímu prríteli z doby studia na jihlavské reálce Jaroslavu Librovi (1892-1914), jehož si vážil jako nadaného umělce a grafika ${ }^{24}$. „[...] zrŕm tebe v slzách: ustydlého v hrobě / na tvrdém srdci země rozechvělé...“25, přičemž rozpoložení lyrického ,já““ odhaluje, že ,[...] nahé srdce schne mi ve vichřici / jak čerstvý chléb, když Jihu větry vanou“ ${ }^{26}$. Vzápětí se objevuje naděje, doufání, víra v lepší časy. Básník ji neprožívá skutečně, v reálné chvíli, nežije ji, nýbrž očekává. Naděje v jeho prvních básních tkví v tom, že je ochoten ji vůbec připustit, i když zažívá těžké chvíle plné pochybnosti: „Však

${ }^{19}$ M. C. Putna, Proměny neměnného..., s. 60-61.

${ }^{20}$ Sluší se připomenout, že kromě zmíněných časopiseckých překladů z Novalise pak Reynek v roce 1915 přeložil pro 13. sborník Florianovy edice „Nova et vetera“ Novalisovy Hymny noci.

${ }^{21}$ B. Reynek, Básnické spisy, ed. M. Chlíbcová, Zlín 1995, s. 11.

22 Ibidem, s. 16.

23 Vyšla ve staroříšské edici „Nova et vetera“, září 1914, sv. 11. (Viz. M. Chlíbcová, Ediční poznámky, [in:] B. Reynek, Básnické spisy..., s. 635).

24 Jaroslav Libra po maturitě studoval na pražském Vysokém učení technickém architekturu, zemřel v březnu 1914 na tuberkulózu. (Srov. stat’ J. Šerých, Kamínek do secesní mozaiky Jaroslava Libry, „Umění“” 1994, č. 6, s. 471).

25 B. Reynek, Básnické spisy..., s. 17.

${ }^{26}$ Ibidem. 
nevěřím. A dětská křídla lámu, / by nová vzrostla, donesla mne výšs“"27, takto zvolá lyrický subjekt. Projevuje se zde víra i naděje, že poté, co budou zničeny „mřŕže smrti“ a kdy se oba prátelé konečně setkají u nohou Panny Marie, s níž je spojován motiv ráje, aby během soudného dne lyrický subjekt „žrel, kdy oslepí mne Vzkř́íšení: / pak s Tebou pochopím i bolest Kř́iže“e28.

Autorova grafika velkých písmen u pojmů z náboženské oblasti (Vzkříšení, Kř́žž), které jsou povýšeny do roviny symbolu, stejně jako grafické zvýraznění kurzivou slova $z \check{r} e l$, nejsou náhodné. Na symbol kříže, jenž je přítomný v každé Reynkově sbírce, se klade značný důraz, nebot' obět' a utrpení Krista mají nadčasovou platnost. Básník si zároveň uvědomuje význam zástupné oběti, proto může být tento obraz chápán jako jinotaj, jehož prostřednictvím se vkládá na Kristova bedra utrpení celého současného světa a doby. V křest’anské teologii smrt neznamená naprosté ukončení existence. Strach ze smrti je překonán nadějí a očekáváním vzkř́išení. Katolická teologie hovoří o duši, která se skrze očistec dostává do nebe. František Valouch v článku Básník duše a samoty Bohuslav Reynek vyzdvihuje mimo jiné právě Reynkovo chápání bytí duše ${ }^{29}$. Hovoří o ,věčnosti duše“, s níž může člověk udržovat vztah s transcendentnem. V Reynkově poezii pak vnímá snahu o osamostatnění duše od těla, aby mohla směřovat $\mathrm{k}$ věčnosti. Reynkovo pojetí smrti je spojeno s osobní vírou. Smrt je vykupitelkou, je apostrofována (jako „Sestra Smrt“) nebo oslavována („Evina dcero prvorozená““30 v básni Smrti) a je součástí života s Bohem. Smrt není zmiňována jako konec veškerého bytí, jen jako konec utrpení a bolesti. Není spojena se strachem a nejistotou, ale s naprostým odevzdáním, smířením, s jistotou vzkřríšení a následného života věčného.

Toto očekávání světlejšího okamžiku se zřetelně projevuje v básníkově přístupu k smrti. Vidí v ní něco krásného, stejně tak jako spatřuje krásu v zemřelých. Jeho očarování tímto posmrtným světem uchvacuje v litanicky intonované skladbě nazvané výstižně Mrtví ze sbírky Smutek Země (1924):

Krásné a spravedlivé jest umírání, / mrtvých úsměv jest jako z pastvin vání, / jako půlky jablek zimních kosti jich skrání. // Jejich ruce jsou jako svadlé podzimní listí, / všecky žilky a cévy možno si v nich sčísti, / jako z listu bílého lze jim z dlaní čísti. // Ruce jejich jsou tiché a studené / jako luna, jako úsvit dne, / pokojny, že úzkost žádná jimi nepohne. // Mrtví jsou ovoce ze slunných snětí, / uzrávše do klína Panina letí, / mrtví jsou nejprudší naděje děti. // Mrtví jsou zora, mrtví jsou kuropění, / mrtví jsou rosa, mrtví jsou ptáci, mrtví jsou východu rdění, / mrtví jsou paprskové ze tmy chtíčů vykoupení, // mrtví jsou Světlo, jež z této země už není ${ }^{31}$.

K této ukázce nelze než uvést výstižný názor Mojmíra Trávníčka:

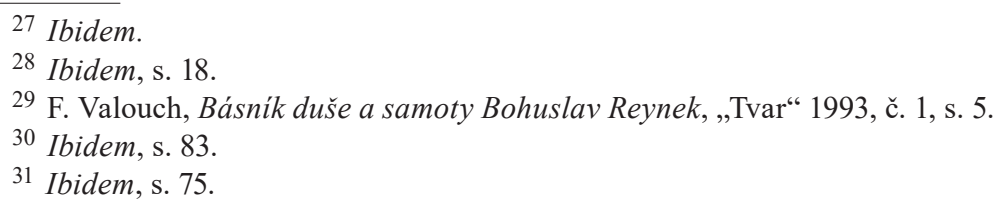


Jedním z prvků, který potvrzuje nefilozofické, neteoretické východisko Reynkovy křest’anské tvorby, je takřka od samých začátků nepřetržitý rozhovor se zemřelými, nekončící dialog, který udržuje vědomí souvislosti, neustále intenzivnější a hlubší. Trvalá a neodbytná př́itomnost mrtvých mezi živými vstupovala do jeho básní jako jedna z nejsamozřejmějších realit ${ }^{32}$.

Uved’me ještě jeden úryvek Reynkovy básně ze sbírky Smutek země, která přes svůj zdánlivě morbidní název Rakvi ukazuje na přirozenost víry, jejíž niterný prožitek dává mystériu smrti pevný půdorys:

nenít úsměvu tak sladkého a trvalého / jako úsměv mrtvých, / kteří s Nevěstou spí / černou, ale krásnou, / sametovou Smrtí, / v rakvi plodné; // ó, snad rty mé světlem v tobě vzplanou, / mluviti již nemohouce, / by pak chválili / Dceru Boží, / hlubokou Smrt! ${ }^{33}$

Ostatně, jak podotýká Trávníček, vztah k mrtvým a ke smrti, který měl u dekadentů nebo u některých mladších básníků na začátku 30. let minulého století přídech morbidnosti, je u Reynka něčím absolutně kladným, oživujícím a srdečným, stejně jako vztah $\mathrm{k}$ domovu, $\mathrm{k}$ dětství a $\mathrm{k}$ důvěrným věcem rodného kraje. To všechno je království Boží, země živých i zemřelých, společenství svatých. Vedle Reynka prožíval toto společenství i Jakub Deml ${ }^{34}$, jehož sbírka Moji přátelé (1913), reprezentující jakýsi „lidský herbáŕc, ze kterého vyzařuje touha po harmonickém společenství lidí i př́ŕrody, měla vliv na řadu Reynkových básní, např́iklad ze sbírky Smutek Země ${ }^{35}$. Avšak dětství, které je rájem ztraceným, nenávratně pominulo: „dětství, ó dětství! Koutku ráje, z něhož mne vyhnali!“‘36 (Útočiště v nevinných). Ráje lze dosáhnout jen smrtí a setkáním se zmrtvýchvstalým Kristem. Právě dětský úžas, jak si Reynek nepochybně uvědomoval, je básnickým principem, jenž snímá ze zvířat a věcí jejich obyčejnost a šed', ba i předsudek, že jsou nepoetické a všední. Totiž právě jimi Reynek zaplňuje svůj lyrický sen o ráji, $\mathrm{v}$ němž panuje harmonie a $\mathrm{v}$ němž se snáze navazuje kontakt $\mathrm{s}$ př́rodou a se zvířaty než s lidmi. Díky tomuto naivnímu přístupu k realitě, díky němuž je obrušována její diskontinuita, je hlavním a nejpodstatnějším tématem Reynkových raných veršů hledání ráje ${ }^{37}$.

[...] a v oči vlhké dobrotou obracím oči své prosebné: / až zahřejete Ježíška, mne také zahřejte, i mne! ${ }^{38}($ Koleda $)$

${ }^{32}$ M. Trávníček, Hlad duše živé. Básnický odkaz Bohuslava Reynka, [in:] idem, Sdílet věčné, Olomouc 2002, s. 38.

33 B. Reynek, Básnické spisy..., s. 139.

${ }^{34}$ M. Trávníček, Hlad duše živé..., s. 38-39.

35 „Stačí si poslechnout názvy básní: Dubnový déšt, Holubưm v strništi, Jabloním na zahradě, Kukačce, Mateřídoušce. Jedině při takto »dolů upřeném《 pohledu je básník mocen bezprostřední radosti“ — M. C. Putna, Proměny neměnného..., s. 63.

${ }^{36}$ B. Reynek, Básnické spisy..., s. 77.

${ }^{37}$ Srovnej J. Med, Od snu o ráji k prožitku Apokalypsy (K básnickému typu Bohuslava Reynka), [in:] idem, Spisovatelé ve stínu, Praha 1995, s. 116.

38 B. Reynek, Básnické spisy..., s. 50. 
Nicméně ani sebeintenzivnější prožitek snu o ráji dětství nemůže zahladit cestu k pravému ráji, která vede údolím smrti:

Dlouho jsem již mrzl na skalině bídy, / neviděl jsem bylin, zvířat ani lidí, // zato plouživých a krutých mátoh tlupy, / jak se chechtají a Naděje tvář tupí; // hlady skučel jsem a nemohl se hnouti / vyschl jako staré povržené proutí: // viz, jak vnitřnosti mé se kají, / hada siroby jen kostí mých klec tají — // Pane, ještě dnes bych s tebou chtěl být v Ráji... ${ }^{39}$ (Pane, ještě dnes...)

Reynkovo katolické vyznání se neprojevuje prvoplánovým výkladem evangelijní zvěsti a starozákonních př́iběhů, ale zaujme upř́imným citovým prožitkem lyrického subjektu, jenž se uměleckým slovem a v rámci své náboženské orientace vypořádává s přijetím svého životního údělu. Obrací se k Panně Marii a jejímu synovi - Spasiteli, zejména při vystižení procesu umírání a smrti. Tragické tóny zaznívající v této poezii odkazují ke zkáze, která je zemi ke konci vyměřeného času prorokována:

[...] země to ví a čeká s velikým bolestným klidem, / pláče, vše vědouc, že křičeti to nesmí lidem... ${ }^{40}$ (Úzkost)

Reynek si oprávněně stýská na chování lidstva:

lidé jsou mrtvi neb hluši a slepi // že nezří a nevědí, k jakému boji / země se třesouc a vzdychajíc stroji‘‘' (Úzkost); Boha lidé nechtějí; lidé jsou smutni; jsou choři ${ }^{42}$. (Neděle)

Umírání se netýká jen lidí, ale také zvířat nebo krajiny. K „umírání krajiny“ se pojí další metafory, jež jsou použity k zobrazení končícího dne nebo pro nastávající závěrečné období roku, tedy zimu. Smrt zviŕrat často odkazuje na starozákonní obětní praxi, která je předobrazem oběti Ježíše Krista. Dobře je to patrné v básni Šípky, zobrazující období podzimního lovu:

Keř, jako pod nožem beran, anděla přiláká, / vydá se, zlatý a rudý, za Izáka [... $]^{43}$.

Existenciálním motivem s platností symbolu je hojně užívaný motiv krve. Ten je spojen s výše uvedeným motivem smrti — člověka, zvířete nebo Ježíše Krista:

Kdyby do zahrady naší vešel Pán / a rudě otiskl ránu své ruky / na bílou zed’ domu / rád bych byl tomu / v bídě svojí $[\ldots]^{44}$. (Kdyby vešel...)

Pomocí př́ivlastku „krvavý“ jsou v této poezii často vystiženy prŕírodní jevy: „Zas vlasy krvavé si suší vrchů témě‘45, formuluje Reynek svůj pocit v básni Zá$\check{r} i$, která je spíše ojediněle v kontextu Reynkovy tvorby napsána ve formě sonetu.

\footnotetext{
39 Ibidem, s. 155.

40 Ibidem, s. 36.

${ }^{41}$ Ibidem.

42 Ibidem, s. 106.

${ }^{43}$ Ibidem, s. 421.

${ }^{44}$ Ibidem, s. 30.

45 Ibidem, s. 20.
} 
Reynek při básnickém vystižení Vykupitelovy smrti zvolna přechází od stvoření a zrodu k zániku, od života ke smrti, která nezůstává konečným stavem. Na motiv smrti proto přirozeně navazuje motiv věčnosti, věčného života. Věčnost, tedy život s Bohem, je silnější než samotná smrt, tudíž se jí lyrický subjekt neobává, nýbrž si stýská pomocí obrazů evokujících expresivní kázání českého baroka:

[...] ale přesmutna jest země, neb ona vidí, / co vidí slunce i mračna, čeho nevidí srdce lidít ${ }^{46}$. (Úzkost)

Přijetí smrti jako radostného východiska na straně jedné a únik do dětství na straně druhé je součástí Reynkova proměnlivého snu o ráji. To se promítá i do obrazu srdce, které je jedním z nejdůležitějších emblémů Reynkovy rané lyriky. Srdce je centrum securitatis, hlubinou bezpečnosti, vysněný ráj pak místem štěstí, tedy locus amoenus.

Mé srdce jest jak v louce pramen, / kol něhož bílé kvítí roste ${ }^{47}$. (Svitání zjara)

Zatímco svět kolem je pln neporozumění a zlosti: (Úzkost)

Srdce lidí černa jsou a studena i slepa, / páchnou jako voda stojatá, jak shnilá řepa ${ }^{48}$.

Básník chce světu darovat vše, co má, včetně svého srdce, ale dar není přijat, a tak se srdce mění v ,černý oharek, jenž obalen jest chrchly / těch pro které žhnulo“49 (Tři písně o srdci).

Básně vznikající po roce 1914 jsou už poznamenány osudovým setkáním $\mathrm{s}$ J. Florianem ${ }^{50}$. (Odlišnost obou etap tvorby si musel zpětně uvědomovat i sám básník, když titul prvotiny je procesuální, záměrně obsahující časové vymezení let 1912-1916).

Reynek celou bytostí přijal víru bloyovsko-lasalettsko-florianovskou a z tohoto přijetí vyplynuly pro jeho poezii tři nové věci: hlavní téma, životní pocit a výrazový prostředek ${ }^{51}$.

Martin C. Putna míní, že hlavním tématem Reynkovy poezie je opakování a oslavování pravdy, kterou lze shrnout do teze: trpící a zlu propadlý svět čeká na Boží zásah, na potopu ohněm, přičemž blízkost nové apokalypsy i záchranu světa zvěstuje Panna Maria, tedy Matka plačící a soucitná. Tyto dva hlavní motivy „florianovské apokalypsy“, tedy plačící Maria a přicházející Oheň, představují spolu s motivem „čekáni““ dominanty v době básníkovy vnitřní konverze. Avšak Reynek se v této etapě identifikace chová jako samostatný umělec, když nábo-

46 Ibidem, s. 36.

${ }^{47}$ Ibidem, s. 19.

48 Ibidem, s. 36.

49 Ibidem, s. 137.

50 Svědectví o životě i přátelích B. Reynka jsou dostupná díky vzpomínkové knize jeho synů Daniela a Jiř́iho, vydané formou rozhovoru Aleše Palána pod názvem Kdo chodi tmami (Praha 2004).

51 M. C. Putna, Proměny neměnného..., s. 61. 
žensko-apokalyptické motivy přetváří v souladu se svým vnitřním světem a básnickým ustrojením, které jsou v církevní tradici zakotveny ještě hlouběji než ve světě Florianově. On totiž umělecky propojuje to, co Florian přináší v té době jako nové, s tím, co sám vytěžil ze starých obrazů církevní liturgie a ikonografie ${ }^{52}$. Ostatně Reynkova láska $\mathrm{k}$ jazyku bohoslužby, zcela individuální větný $\mathrm{i}$ věcný rytmus, formální kázeň a mnoho dalších rysů potvrzuje, že básník nepřeháněl, když se při kterési př́ležitosti svěřil, že jeho nejmilejší knihou je Římský misál. Také trochejský spád některých trojveršů, často umně zakrývaných čtyřveršovými strofami, ukazuje k rytmu církevních sekvencí; koneckonců Reynek mistrně přeložil Stabat mater a Dies irae. Obřadnost, obraznost a rytmus církevních hymnů jsou blízké četným polohám této poezie, přitom není pochyb o inspiraci českou barokní kostelní písní ${ }^{53}$.

Typické pro celou Reynkovu debutantskou sbírku je spojování př́rodního, lyricky pojatého světa s vizí křest’ansky přijímaného řádu, jenž ústí v závěru lidského života spolu s apokalyptickým koncem země samé do konfrontace s dílem spásy Ježíše Krista, v jehož pohledu „těžkost slita jest všech umírání“54 (Zrcadlo). Ač převažuje naděje, odkrývány jsou bolesti duše, která je osaměle vržena do světa, jak je to patrné z básně v próze emblematicky nazvané Samota:

Odvrátiv se, viděl jsem mezi pni sta útlých, modravých mečův; ale setrval jsem: Smrt nemá půvabu ni hrůzy pro ty, kdo jsou takto sami ${ }^{55}$.

Reynek lituje životů lidí a existence světa, který se vzdálil od Boha, s čímž souvisí motiv utrpení. Avšak tak jako je tomu ve starozákonním př́íběhu o utrpení biblického Joba, ani v básních petrkovského rodáka nenalézáme zlořečení Bohu za dopuštění zla. Vedle únavy a bědování stojí pokora, se kterou přijímá takový úděl. V orálně intonovaných dvojverších básně Domov, upomínajících na možný vliv básní podobného typu francouzských básníků Charlese Péguyho (1873-1914) a Paula Claudela (1868-1955), ostatně také překládaných Reynkem ${ }^{56}$, si můžeme povšimnout existenciálních motivů utrpení, samoty a pokory:

Nyní jest podzim, jenž mi Ježíše v krvi a na křiži připomíná, / nebot' dílo zlých i dobrých plno jest, plod vydala svůj všecka hlína. // Země mi naposled požehnala, ví, že nebude již dlouho živa, / v kole červených plamenů sedí, dobré své zlaté ruce si zhřívá. // A já dosud sevřen zdmi a stromy piji život z ruky tvojí, Pane, jako v kytici včela, / ale úzkosti a bídy mojí volání se na chvilenku odmlčela: // Jizvy bolesti starých jako Job čistím si útěch střepy, / a neznámých, nových muk medem rty mé se na sebe lepí ${ }^{57}$.

52 Podrobněji viz M. C. Putna, Česká katolická literatura: Bohuslav Reynek apokalyptik — zdroje a motivy, [in:] L'oeuvre de Bohuslav Reynek - Une éclaircie au loin?, „Essais sur le discours de 1'Europe éclatée“ 2000, č. 16, s. 131-144; následně francouzská verze: La littérature catholique tchéque: Bohuslav Reynek et l'Apocalypse - sources et motifs, s. 145-161.

53 Srov. M. Trávníček, Hlad duše živé..., s. 41-42.

54 B. Reynek, Básnické spisy..., s. 46.

55 Ibidem, s. 22.

56 Srov. M. C. Putna, Proměny neménného..., s. 62.

${ }^{57}$ B. Reynek, Básnické spisy..., s. 41. 
Blízké tomuto motivickému okruhu jsou všechny náboženské motivy, které můžeme rozčlenit poměrně jednoduše na starozákonní, novozákonní a sakrální, přičemž v Reynkově poezii sledujeme jejich časté prolínání. K starozákonním počítejme kromě zmíněné postavy Joba a jeho utrpení i motiv hořícího keře, hada, ráje, Evy, Kaina a Ábela a tak dále, z novozákonních uved’me postavu Krista, Panny Marie, Alžběty, roušky Veroničiny, beránka, plátna či šatů Kristových, motiv posledního soudu ze Zjevení Janova a tak podobně. K sakrálním motivům patří vztah Panny Marie a Krista i dalších svatých, které se vážou k prostředí bohoslužby, kostela, hřbitova, dotvářeném svícemi, křížem a podobně, souvisejícími s křest’anskými svátky a rituály (Svátek zesnulých neboli Dušičky, Letnice, Svátek Ducha svatého a tak dále). Motivy s funkcí symbolu představují rovněž liturgické barvy, jichž je zejména v rané Reynkově poezii velká škála. Specifickou oblast reprezentují motivy venkovské a přírodní.

Všechny výše zmíněné motivy, z nichž jsme si nejčastěji všímali leitmotivu smrti, jsou vždy zapojeny do určitého kontextu. Stávají se tak součástí větších významových celků, které můžeme shrnout pod topos smrti, k němuž vše směřuje (v literárním a symbolickém kontextu Reynkovy poezie samožrejmě v jeho specifickém křestanském pojetí). Jiné motivy, např́klad samoty, utrpení, bolesti, ale i klidu či pokoje, chápeme jako základní intermotivy, které prostupují dvěma prvními Reynkovými sbírkami, na něž jsme jen zčásti soustředili naši pozornost, nebot' jsme všechny z důvodu rozsahu našeho př́spěvku nemohli podrobněji rozebrat. V rámci komparativního výzkumu by pak bylo vhodné sledovat i četné intertextuální relace obsažené v této poezii, použití aluze, citátu, parafráze, reminiscence apodobně. Sem by spadaly i úvahy o transtextuálním navazování poezie na výtvarné podněty a vice versa. Je zřejmé, že tento př́íspěvek zdaleka nemohl vyčerpat všechny nabízené možnosti interpretace a analýzy Reynkovy poetiky.

\section{Bibliografie}

Bohuslav Reynek 1, 2. Katalog výstavy k 100. výroči narozeni, Brno 1992.

Čapek J., Reynek B., Nepřicházeji vhod, Brno 1970.

Halasová D., Bohuslav Reynek, Brno 1992.

Martinek L., Bohuslav Reynek - Samotář z Petrkova, „Slavica Wratislaviensia” 160, 2015.

Martinek L., Kopce jsou lysé, sníh hoři. Zhudebněná poezie Bohuslava Reynka, „Religious and Sacred Poetry. An International Quaterly of Religion, Culture and Education“ 2014, č. 4 (8).

Med J., Od snu o ráji k prožitku Apokalypsy (K básnickému typu Bohuslava Reynka), [in:] idem, Spisovatelé ve stínu, Praha 1995.

Med. J., Reynek B., [in:] Lexikon české literatury 3/II, P-̌̌n, ed. J. Opelík, Praha 2000.

Palán A., Kdo chodi tmami, Praha 2004.

Putna M. C., Česká katolická literatura: Bohuslav Reynek apokalyptik — zdroje a motivy, [in:] L'oeuvre de Bohuslav Reynek - Une éclaircie au loin?, „Essais sur le discours de l'Europe éclatée“ 2000, č. 16; následně francouzská verze: La littérature catholique tchéque: Bohuslav Reynek et l'Apocalypse - sources et motifs.

Putna M. C., Proměny neměnného, [in:] Bohuslav Reynek: Pieta v lod'ce. Grafické a básnické dílo, ed. V. Jirousová, Praha 2002. 
Reynek B., Básnické spisy, ed. M. Chlíbcová, Zlín 1995.

Šerých J., Kamínek do secesní mozaiky Jaroslava Libry, „Uměni““ 1994, č. 6.

Trávníček M., Hlad duše živé. Básnický odkaz Bohuslava Reynka, [in:] idem, Sdílet věčné, Olomouc 2002.

Valouch F., Básník duše a samoty Bohuslav Reynek, „Tvar“ 1993, č. 1.

Záborcová M., Fenomén smrti v české literatuře 20. století, disertační práce, Praha 2007.

\section{Poetics of death in the early work of Bohuslav Reynek}

\section{Summary}

This article is dedicated to the poetics of death in the early works of the Czech poet, translator and graphic artist Bohuslav Reynek (1892-1971). The author focuses his attention on the topos of death, which is the overarching theme that encloses other important motives associated with it and described by the author as "intermotives". Typical of the whole first volume of Reynek's poetry is the combination of the natural world with the vision of a Christian order, which at the end of human life tends toward an apocalyptic end of the earth and confrontation with the salvation of Jesus Christ.

Keywords: Bohuslav Reynek, topoi, death, motives, intermotives

\section{Poetyka śmierci we wczesnej twórczości Bohuslava Reynka}

\section{Streszczenie}

Artykuł poświęcony jest poetyce śmierci we wczesnych dziełach czeskiego poety, tłumacza i grafika Bohuslava Reynka (1892-1971). Autor tekstu skupia swoją uwagę na toposie śmierci, na który składają się ważne motywy z nim związane, nazwane przez niego intermotywami. Dla całego pierwszego tomu poezji Reynka typowe jest połączenie świata natury z wizją chrześcijańskiego porządku, w którym kres ziemi i ludzkiego życia w konfrontacji z dziełem zbawienia Jezusa Chrystusa zmierza ku apokalipsie.

Słowa kluczowe: Bohuslav Reynek, topos, śmierć, motywy, intermotywy 